\title{
Identifikasi Senyawa Boraks pada Bakso secara Non Destruktif Menggunakan Spektrum Inframerah Dekat dan Principle Component Analisys
}

\author{
Budiara Pahlawan $^{1}$, Yunardi ${ }^{2}$, Agus A Munawar ${ }^{3}$, Friska Meirisa $^{4}$, Hesti Meilina ${ }^{5 *}$ \\ ${ }^{1}$ Program Studi Magister Teknik Kimia, Fakultas Teknik, Universitas Syiah Kuala, Banda Aceh \\ ${ }^{3}$ Program Studi Teknik Pertanian, Fakultas Pertanian, Universitas Syiah Kuala, Banda Aceh \\ *Koresponden email: hesti.meilina@ unsyiah.ac.id
}

Diterima: 5 Oktober 2020

Disetujui : 20 Oktober 2020

\begin{abstract}
The combination of Near Infrared (NIR) Spectroscopy and multivariate analysis using Principle Component Analysis (PCA) was developed to detect the presence of borax in meatballs. The conventional analysis used to detect the presence of borax has been considered inefficient because it is only able to qualify for the presence of borax, but cannot determine the dose of borax used. This study aimed to identify the presence of borax in meatballs using NIR Spectroscopy in the 1000-2500 nm range and maximize PCA performance by combining MSC and SNV pre-treatment with Savitzky Golay second derivative. The results showed that the identification of borax can occur at a wavelength of $1800-2500$ $\mathrm{nm}$, which is indicated by vibrations at a wavelength of $1865 \mathrm{~nm}$ with the atomic structure of C-Cl and the combination of pre-treatment of the second derivative of Savitzky Golay also successful for grouping the data to be better.
\end{abstract}

Keyword: Borax, Meatballs, MSC, NIR Spectroscopy, PCA, SNV

\begin{abstract}
Abstrak
Kombinasi NIR Spectroscopy dan analisis multivariat menggunakan Principle Component Analysis (PCA) dikembangkan untuk mendeteksi keberadaan boraks yang terdapat di dalam makanan bakso. Analisis secara konvensional yang digunakan untuk mendeteksi keberadaan boraks di dalam makanan selama ini dianggap masih belum efisien karena hanya mampu untuk mengkualifikasi keberadaan boraks, namun tidak dapat menentukan dosis boraks yang digunakan. Penelitian ini ditujukan untuk mengindentifikasi keberadaan boraks yang terdapat pada bakso menggunakan NIR Spectroscopy pada rentang panjang gelombang 1000-2500 $\mathrm{nm}$ dan memaksimalkan kinerja PCA dengan cara mengkombinasikan pre-treatment MSC dan SNV dengan turunan kedua Savitzky Golay. Dari hasil penelitian menunjukkan bahwa identifikasi boraks dapat terjadi pada panjang gelombang $1800-2500 \mathrm{~nm}$ yang ditandai adanya getaran pada panjang gelombang $1865 \mathrm{~nm}$ dengan struktur atom $\mathrm{C}-\mathrm{Cl}$ dan kombinasi pre-treatment turunan kedua Savitzky Golay juga berhasil mengelompokkan data menjadi lebih baik.
\end{abstract}

Kata kunci: Boraks, Bakso, MSC, NIR Spectroscopy, PCA, SNV

\section{Pendahuluan}

Boraks merupakan salah satu bahan kimia yang umumnya digunakan dalam pembuatan deterjen, pembasmi serangga, dan pengawet kayu. Namun saat ini banyak industri rumah tangga yang menggunakan boraks sebagai bahan tambahan pada olahan bahan makanan yang mereka produksi seperti bakso, mie basah, tahu dan siomay. Penggunaan boraks sebagai tambahan pada olahan makanan telah dilarang oleh pemerintah dan tercantum dalam Peraturan Menteri Kesehatan Republik Indonesia No. 722/MenKes/per/IX/88 dengan pernyataan bahwa salah satu bahan tambahan pada makanan yang dilarang adalah boraks [1].

Penggunaan boraks pada makanan dapat mengakibatkan timbulnya kerusakan didalam organ tubuh seperti, merusak organ pusat syaraf, ginjal, testis, dan kerusakan hati apabila dikonsumsi secara terus menerus. Mengkonsumsi boraks dengan dosis yang tinggi juga akan berakibat fatal pada organ tubuh, dimana dosis fatal yang dapat dikonsumsi oleh orang desawa adalah 15-20 gram dan untuk anak-anak adalah 6 gram [2].

Penggunaan kertas kunyit dan tusuk gigi untuk mengindentifikasi kandungan boraks pada makanan. Metode ini umumnya digunakan karena murah, mudah, dan dapat dilakukan langsung ditempat (on-site) [3] namun metode ini belum dapat digunakan untuk menghitung berapa banyak boraks yang 
berada dalam bakso. Pengembangan penggunaan Spektrofotometri UV-VIS telah berhasil dilakukan untuk menentukan konsentrasi boraks yang terdapat pada bahan makanan. Namun, adanya penggunaan bahan kimia menjadikan metode ini kurang efisien dan membutuhkan waktu untuk preparasi [4].

Pada beberapa tahun terakhir penggunaan Near Infrared (NIR) Spectroscopy telah banyak dikembangkan untuk mendeteksi komposisi bahan yang terdapat di dalam makanan dengan mudah, cepat dan akurat. Kombinasi NIRS Spectroscopy dan Chemometrics menjadikan metode ini menjadi salah satu metode alternatif yang dapat digunakan untuk pengawasan dan keamanan pangan yang beredar di pasar. Kombinasi kedua metode ini telah dilakukan untuk mendeteksi adanya kandungan babi yang terdapat di dalam bakso [5], mengevaluasi kualitas produk perikanan dan juga telah dikembangkan untuk autentifikasi kehalalan pada bahan makanan [6]-[10]. Oleh sebab itu, penelitian ini dilakukan dengan tujuan untuk mengindentifikasi boraks yang terdapat pada bakso menggunakan NIR Spectroscopy yang dikombinasikan dengan analisis multivariat Principle Compenet Analysis (PCA) dan pemilihan pretreatment yang tepat sehingga dihasilkan model analisis kualitatif tanpa supervisi untuk menemukan perbedaan antara bakso yang mengandung boraks dan tanpa boraks.

\section{Metode Penelitian \\ Waktu dan Tempat Penelitian}

Penelitian ini dilakukan bulan Agustus 2018 sampai September 2019 di Laboratorium Bioproses yang digunakan untuk proses persiapan sampel, Laboratorium Teknik Lingkungan dan Laboratorium Pertanian untuk melakukan analisis sampel yang telah disiapkan. Ketiga Laboratorium ini berada di Jurusan Teknik Kimia dan Jurusan Pertanian Universitas Syiah Kuala.

\section{Preparasi Sampel}

Penelitian ini menggunakan sampel bakso artifisial yang terbuat dari daging ayam dengan variasi konsentrasi boraks $(0,5 \mathrm{~g} ; 1 \mathrm{~g} ; 1,5 \mathrm{~g} ; 2 \mathrm{~g} ; 2,5 \mathrm{~g}$, dan $3 \mathrm{~g})$ untuk setiap $60 \mathrm{~g}$ bakso. Adonan bakso yang telah dicampurkan boraks kemudian dicetak dan direbus.

\section{Akuisisi spektrum}

Pengukuran spektrum bakso dilakukan pada rentang panjang gelombang 1000-2500 nm menggunakan alat FT-IR IPTEK T 1516. Sampel bakso yang digunakan sebanyak 7 sampel (berdasarkan konsentrasi) dimana pengambilan spektrum dilakukan pada 4 titik, yaitu bagian depan, belakang, kanan, dan kiri untuk setiap sampel dimana untuk setiap titik dilakukan 3 kali pengulangan pengukuran/scanning. Total jumlah spektrum yang menjadi database untuk analisis selanjutnya adalah sebanyak 84 spektra. Hasil akuisisi spektrum disimpan dengan 3 bentuk file, yaitu *.SPA., *.JDX, dan *.CSV. Data absorbansi diperoleh dengan cara mentransformasikan nilai reflektan/pantulan kedalam bentuk $\log (1 / \mathrm{R})$ yang diperoleh menggunakan Unsclamber Software ® $X$ version 10.1. Untuk mengidentifikasi kandungan boraks yang ditambahkan pada bakso, digunakan metode Principal Component Analysis (PCA) sebagai metode unsupervised classification untuk mengidentifikasi dan mengelompokkan data berdasarkan akuisisi spektrum yang telah dilakukan. PCA menggunakan prosedur matematis yang mengubah seperangkat variabel respons yang mungkin berkorelasi menjadi serangkaian variabel baru yang tidak berkorelasi.

\section{Hasil Dan Pembahasan}

\section{Fitur spektrum sampel bakso yang mengandung boraks dan tanpa boraks}

Koreksi spektrum bakso yang mengandung boraks dengan absorbansi yang ditransformasikan menjadi \% transmitan dapat dilihat pada Gambar 1. Akuisisi spektrum dilakukan pada panjang gelombang 1000 - $2500 \mathrm{~nm}$, tanpa adanya proses pre-treatment yang dilakukan menjadikan spektrum memilki banyak kesalahan, kebisingan, gangguan, dan menjadikan spektrum saling tumpang tindih. 


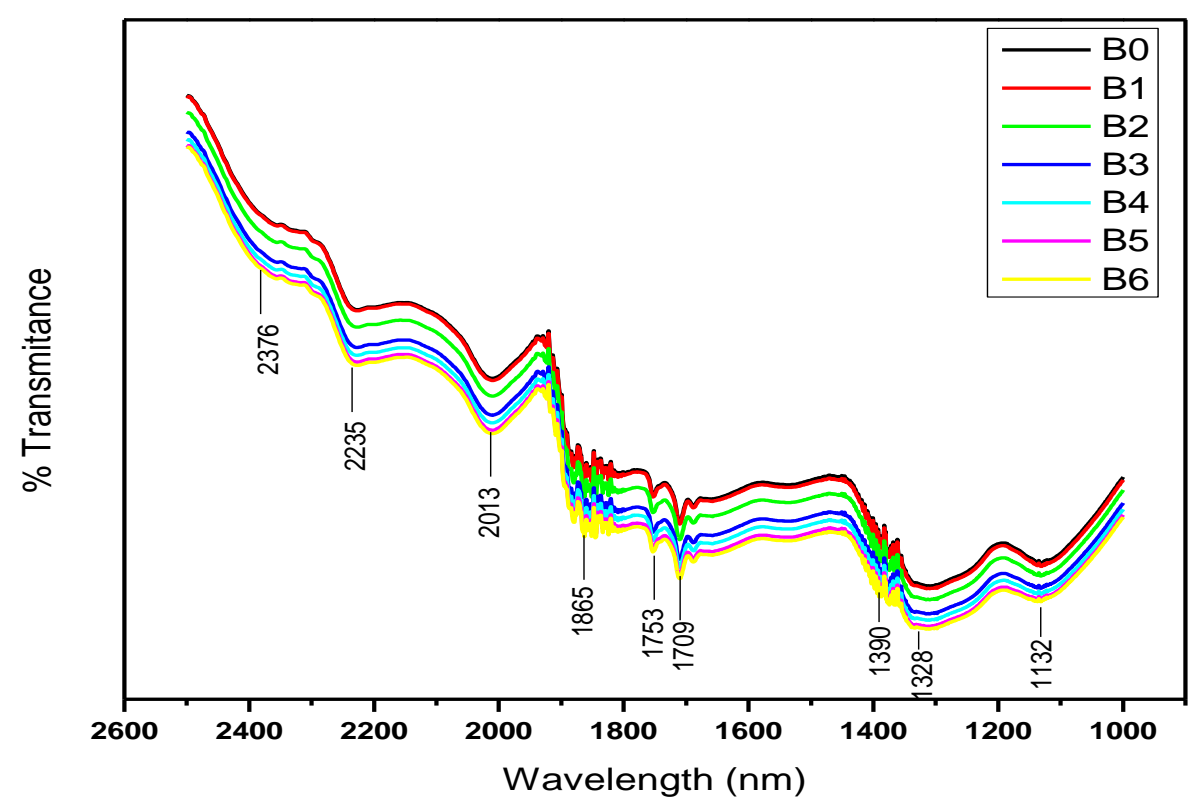

Gambar 1. Spectrum dari sampel bakso yang mengandung boraks dan tanpa adanya boraks Ket: Kandungan boraks (B0= 0 gr; B1=1,5 gr; B2=1 gr; B3=1,5 gr; B4= 2 gr; B5= 2,5 gr; B6= 3 gr) Sumber: Hasil penelitian, 2019

Gambar 1 menunjukkan bahwa adanya getaran yang mempresentasikan ikatan senyawa kimia yang terdapat pada spektrum, hal ini terjadi karena adanya cahaya yang melewati sampel sehingga memberikan suatu reaksi terhadap sampel yang digunakan [11]. Perbedaan nilai absorbansi ditemukan dengan sembilan daerah yang memilki karakteristik pada puncak spektrum seperti terlihat pada Gambar 1. Dimana pada peak $1132 \mathrm{~nm}$ terjadi peregangan nada kedua $\mathrm{C}-\mathrm{H}$, peak $1328 \mathrm{~nm}$ dan peak 1320 terjadi kombinasi peregangan C-H [12].

Getaran pada nada pertama C-H juga terdapat pada peak $1709 \mathrm{~nm}$ dan $1753 \mathrm{~nm}$ yang masingmasing menandakan adanya stuktur senyawa $\mathrm{CH}_{3}$ dan aromatik [13][14]. Pada peak 1865 terjadi getaran peregangan nada yang menandakan adanya stuktur atom $\mathrm{C}-\mathrm{Cl}$ yang merupakan jenis bahan kimia Chlorinated hydrocarbons [14]. Bahan ini merupakan salah satu senyawa insektisida yang merupakan salah satu bahan yang juga digunakan untuk pembasmi serangga. Kombinasi peregangan atom $\mathrm{N}-\mathrm{H} / \mathrm{C}=\mathrm{O}$ terjadi pada peak $2013 \mathrm{~nm}$ dengan struktur spektum getaran NH dan amida 1. Pada peak $2235 \mathrm{~nm}$ muncul serapan atom $\mathrm{CHO}$ dan pada peak $2376 \mathrm{~nm}$ merupakan getaran yang muncul karena peregangan atom C$\mathrm{H}$ serta kombinasi peregangan atom C-C yaitu jenis senyawa yang mengandung lipids [14].

\section{Principal Component Analysis (PCA)}

Analisis boraks pada sampel bakso menggunakan PCA tanpa menggunakan pre-treatment berhasil mengelompokkan data dengan baik seperti yang terlihat pada Gambar 2a dengan total varian yang didapatkan sebesar $100 \%$. Penggunaan PCA sebagai metode analisa boraks pada sampel bakso mampu mengklasifikasikan boraks dengan baik dimana besar varian yang diberikan pada PC1 sebesar 100\% dan PC2 0\%. Pada kondisi ini PC2 tidak memberikan informasi atau keberadaan boraks pada sampel bakso yang digunakan. 
a)

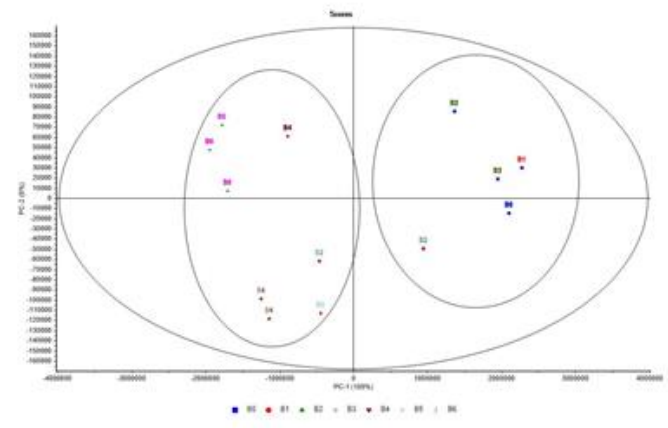

b)

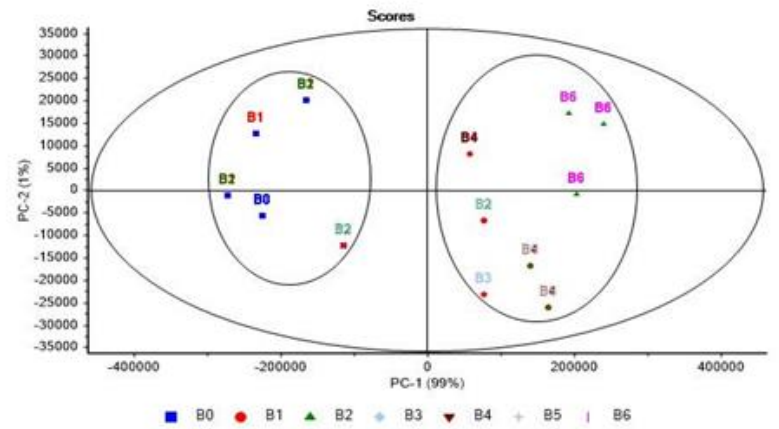

c)

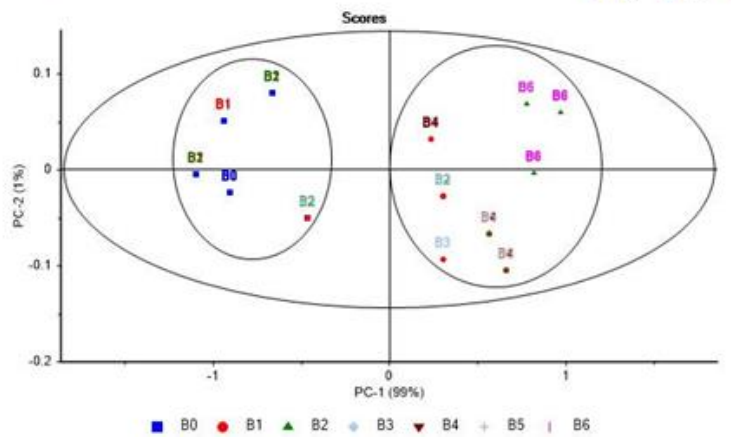

Gambar 2. Klasifikasi kandungan boraks pada sampel bakso menggunakan PCA: (a) raw data, (b) pre-treatment MSC, and (c) pre-treatment SNV Sumber: Hasil penelitian, 2019

Analisis Spektrum menggunakan PCA dengan Multiple scatter Correction (MSC) yang digunakan sebagai pre-treatment berhasil mengelompokkan data pada sampel bakso seperti yang disajikan pada Gambar 2b dengan varian yang diberikan pada PC1 adalah 99\% dan PC2 adalah 1\%. Metode analisa ini dianggap berhasil diterapkan sebgai metode analisis untuk mengkualifikasikan adanya kandungan boraks pada sampel bakso. Analisis spektrum menggunakan PCA dengan SNV sebagai pre-treatment memberikan hasil yang baik dimana nilai varian yang diberikan sebesar 99\% dan $1 \%$ pada PC1 dan PC2.

Analisis beban pada PCA sangat penting untuk dilakukan, karena mampu menunjukkan panjang gelombang atau daerah spesifik dalam kisaran NIR terkait dengan variabelitas yang diamati dalam plot skor PCA. Perbedaan yang jelas antara beban di PC1 dan PC2 diamati, dimana hasil menunjukkan bahwa informasi spektral yang berbeda mungkin terkait dengan jaringan yang berbeda atau kombinasi sampel yang dianalisis [13]. Faktor analisis yang digunakan untuk melihat variabel baru dalam jumlah yang lebih kecil dapat dilakukan menggunakan PCA sebagai dasar, serta memberikan perbedaan antara konsentrasi satu dan konsentrasi yang lainnya. Hasil dari PCA membuktikan bahwa NIRS mampu mengelompokkan data berdasarkan tingkat konsentrasi boraks yang ada pada sampel bakso [15].

PCA adalah salah satu dari banyaknya metode analisis yang digunakan untuk menemukan hubungan mendasar antara penanda biologis dan kimia dari jumlah besar data set. Selama proses PCA, untuk mendefinisikan variabel-variabel yang hanya berguna untuk mendeteksi pemalsuan dalam bahan makanan atau untuk mengurangi data set yang menggunakan variabel relevan sangat penting untuk digunakan. Secara statistik penggunaan PCA dilakukan untuk membentuk pemalsuan sidik jari atau disebut juga dengan pengurangan dimensi [16].

Pada Gambar 3 disajikan penggunaan PCA dengan kombinasi pre-treatment antara MSC dengan turunan kedua dan SNV dengan turunan kedua dari Savitky-Golay. Dari gambar tersebut untuk memisahkan sampel bakso yang menggunakan boraks dan sampel bakso tanpa ada boraks terlihat sangat jelas. Namun, dari kedua kombinasi pre-treatment menunjukkan total varian yang diberikan hanya $61 \%$ dimana pada PC1 sebanyak 52\% dan pada PC2 sebanyak $9 \%$. 
a)

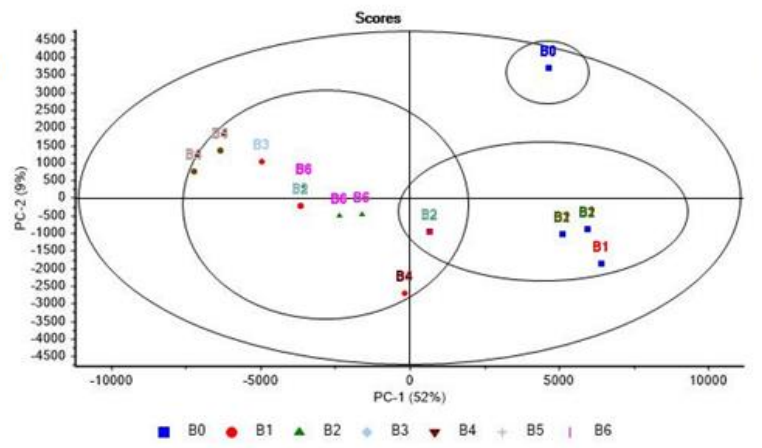

b)

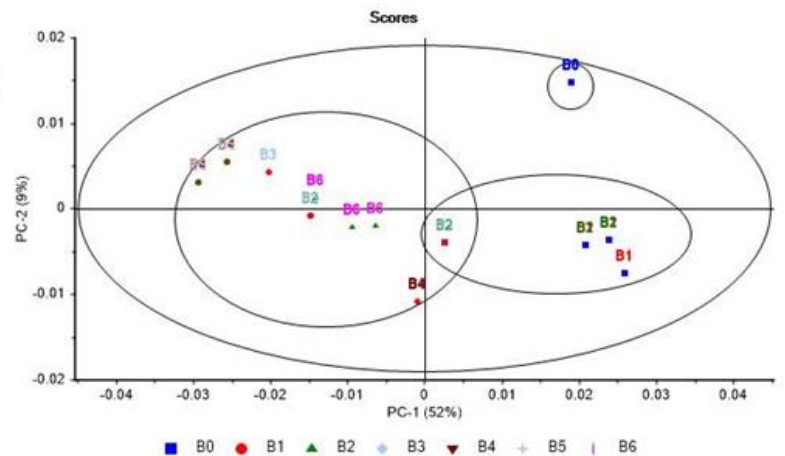

Gambar 3. Klasifikasi kandungan boraks pada sampel bakso dengan kombinasi pre-treatment (a), kombinasi pretreatment MSC dan $2^{\text {nd }}$ Derrivative by savitky-golay (b) kombinasi pre-treatment SNV dan $2^{\text {nd }}$ Derrivative by Savitzky-Golay

Sumber: Hasil penelitian, 2019

Dari Gambar 3 menjelaskan tentang penggunaan kombinasi dari pre-treatment MSC dengan 2nd Derrivarive Savitky-Golay dan SNV dengan 2nd Derrivarive Savitky-Golay. Dari hasil kombinasi pretreatment yang digunakan menjelaskan bahwa hasil klasifikasi dari identitas borak yang terdapat didalam bakso menjadi lebih baik karena bakso tanpa penggunaan boraks berada dalam satu kelompok tersendiri. Dari hasil uji PCA ini juga memberikan total varian sebesar $61 \%$ dan dapat dinyatakan bahwa pengujian ini memberikan hasil yang cukup baik.

\section{Kesimpulan}

Dari hasil yang diperoleh, dapat disimpulkan bahwa dengan adanya pre-treatment yang dilakukan terhadap akuisisi spektrum pada sampel bakso yang mengandung boraks mampu meningkatkan tampilan spektrum. Pada metode analisa menggunakan PCA dengan raw data dan penggunaan pre-treatment MSC dan SNV masih memiliki kemiripan yang sangat jelas. Namun dengan adanya kombinasi pre-treatment yang dilakukan antara MSC dengan $2^{\text {nd }}$ Derrivative dan SNV dengan $2^{\text {nd }}$ Derrivative mampu menyajikan perbedaan yang lebih signifikan anatar sampel bakso yang mangandung boraks dan tanpa adanya boraks.

\section{Referensi}

[1] A. F. Medya Ayunda Fitri, Yulia Tri Rahkadima, Trisna Kumala Dhaniswara, Qurrota A'yuni, "Identifikasi Makanan Yang Mengandung Boraks Dengan Menggunakan Kunyit Di Desa Bulusidokare, Kecamatan Sidoarjo, Kabupaten Sidoarjo," J. Sci. Soc. Dev., vol. 1, no. 1, pp. 9-15, 2018.

[2] R. A. I Nyoman Trias Suadnyana, Resti Arania, "Perbedaan pengaruh pemberian boraks dengan dosis bertingkat terhadap gambaran histopatologi organ ginjal tikus putih jantan (, J. Ilmu KedoJkteran dan Kesehat., vol. 1, no. 1, pp. 112-118, 2014.

[3] S. A. Warni, "Analisis Boraks Pada Bakso Daging Sapi C Dan D Yang Dijual Di Daerah Lakarsantri Surabaya Menggunakan Spektrofotometri," J. Ilm. Mhs. Univ. Surabaya, vol. 2, no. 2, pp. 1-10, 2013.

[4] E. Kurniawati, A. Rohman, and K. Triyana, "Analysis of lard in meatball broth using Fourier transform infrared spectroscopy and chemometrics," MESC, vol. 96, no. 1, pp. 94-98, 2014.

[5] B. Kuswandi, K. A. Cendekiawan, N. Kristiningrum, and M. Ahmad, "Pork adulteration in commercial meatballs determined by chemometric analysis of NIR Spectra," J. Food Meas. Charact., pp. 313-323, 2015.

[6] A. K. H. B. A. Hakim, "Identifikasi Pola Khas Spektra Infra Merah Protein Kulit, Kikil Dan Rambak Babi Dan Sapi," 2011.

[7] A. Rohman and Y. B. Che Man, "Analysis of Pig Derivatives for Halal Authentication Studies," Food Rev. Int., vol. 28, no. 1, pp. 97-112, 2012.

[8] M. Gishen and D. Cozzolino, "Feasibility study on the potential of visible and near infrared reflectance spectroscopy to measure alpaca fibre characteristics," no. January 2014, 2007.

[9] N. A. Karim and I. I. Muhamad, "Detection Methods and Advancement in Analysis of Food and Beverages: A Short Review on Adulteration and Halal Authentication," no. June, 2018. 
[10] K. A. Cendekiawan, B. Kuswandi, and N. Kristiningrum, "Deteksi Daging Babi pada Sampel Bakso Menggunakan Metode Near Infra Red (NIR) dan Kemometrik sebagai Verifikasi Kehalalan (Detection of Pork in Beef Meatball Sample using Near Infra Red and Chemometrics as Halal Verification)," Pustaka Kesehat., vol. 3, no. Vol 3, No 1 (2015), pp. 34-38, 2015.

[11] B. G. Osborne, "Near-infrared Spectroscopy in Food Analysis," pp. 1-14, 2006.

[12] Metrohm AG, "NIR Spectroscopy "A guide to near-infrared spectroscopic analysis of industrial manufacturing processes,"” CH-9101 Herisau, Switzerland. 8.108.5026EN, 2013.

[13] J. J. Roberts, J. C. Motin, D. Swain, and D. Cozzolino, "Research Article A Feasibility Study on the Potential Use of Near Infrared Reflectance Spectroscopy to Analyze Meat in Live Animals: Discrimination of Muscles," vol. 2017, 2017.

[14] J. Workman and L. Weyer, Practical Guide to Interpretive Near-Infrared Spectroscopy, 13: 978-1. United States of America, 2008.

[15] I. and M. M. F Yuwita, "Non-destructive Evaluation of Fat Content of Coffee Beans Solok Radjo Using Near Infrared Spectroscopy Non-destructive Evaluation of Fat Content of Coffee Beans Solok Radjo Using Near Infrared Spectroscopy,” pp. 0-7, 2019.

[16] L. L. and D. B. K. P Putnik1, D Granato2, A Gomes Da Cruz3, O Ye Rodionova4, A Pomerantsev4, $\mathrm{G}$ Rocchetti5, "Trends in chemometrics and meat products Trends in chemometrics and meat products," 2019. 